of steel cable required for keeping the trawl on the bottom. Here the deep-sea echograph proved a most valuable asset, since it enabled us to keep the depth in which the trawl was being towed under permanent control and also to pick and choose our trawling ground beforehand, so as to avoid an uneven bottom, dangerous to the gear. Very good catches, both of fishes and of invertebrate organisms, from great depths were made, some of them very rare or even new to science. The deepest haul, made to the north-east of the Virgin Islands, gave conclusive proof that even in depths exceeding 4,200 fathoms (7,600-7,900 metres) bottom-living organisms exist, such as sea-cucumbers and -worms. In all probability even the greatest depths of the ocean are inhabited, although by a sparse and highly specialized fauna.

By means of a large sledge-net towed along the bottom in a depth of about 2,800 fathoms to the south-east of the Bermudas, several hundred manganese nodules, some of them of fairly large size, were obtained. Their rate of radial growth is now being determined by radium measurements in their difierent layers. Quite near this locality an interesting core was raised by means of a core sampler of specially wide bore. Its uppermost layer was a manganese crust followed by a terracotta-coloured paste rich in iron. But the lower parts of the core also gave a rich display of varying colours.

In general, the results both from the sediment work, the oceanographic series, and the deep-sea trawling lend support to the view that adequate technical resources are now available for extensive research in great ocean depths; such research is of great importance not only for oceanography but also for the almost novel science of submarine geology. A few points which appear to be specially worthy of future study may be mentioned.

(1) The surface layers of the deep-sea deposits in their interrelation with the bottom water. Here water bottles closing at definite heights above the bottom and core-samplers imparting a minimum of disturbance to the semifluid uppermost sediment layer and at the same time giving sufficient material for detailed analysis, centimetre by centimetre, should be used. In connexion with such sampling, the plankton community existing in the upper water layers, especially the foraminifera, should be sampled by means of quantitative plankton catchers.

(2) The raising of long sediment cores has been proved feasible during the expedition, in spite of fairly strong wind and ocean swell. The region we have explored should in future be extended to higher latitudes on both hemispheres. In such long cores reaching well back into the late Tertiary, both the pelagic and the benthonic foraminifera should be studied, with the view of ascertaining by how much the temperatures of the bottom layers were then higher than at present.

(3) The geothermal gradient in the deep-sea bottom should be extensively measured by means of an improved technique. A point of special interest will be to extend these measurements to regions both within and outside areas of pronounced volcanic activity.

(4) Measurements of sediment thickness by means of an improved technique should be carried out in great depths, preferably also by means of depthcharges exploding below the surface of the sediment.

(5) Continuous records of the bottom profile across the oceans should be taken wherever possible. If naval ships on ocean-crossing cruises could be pro- vided with the supersonic echographs of great range now available at moderate costs, their cruises might afford most valuable material both for bathymetrical and morphological studies of the ocean floor, where hitherto so very little is known.

In the first years of this century an international organisation was set up for co-ordinated systematic work in physical oceanography and in biology over the shelf area and the adjacent continental slope off the coasts of north-west Europe. The International Council for Sea Investigations has carried out invaluable work during the half-century of its existence. The much vaster field offered by the deep ocean now seems to call for a similar co-ordination of efiorts on an international scale. Great Britain, where deep-sea oceanography was born, would seem destined to take a leading part, on the European side, of this future work.

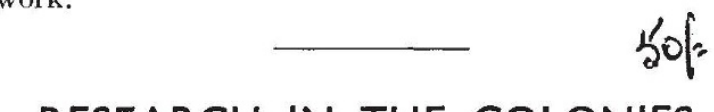

\section{RESEARCH IN THE COLONIES}

$\mathrm{W}^{\mathrm{sen}}$ ITH its third issue under the title "Colonial Reseafch (1648-1949)" * the collection of annual reports dealn with Colonial research now appears to have taken something like final shape. Under that title the pipsent volume of 134 pages includes the annuafepde of the Colonial Research Council, the sixth a mual report of the Colonial Products Research o. inst, the fifth annual report of the Colonial Social 5 C Ence Research Council, the fourth annual reports othe Colonial Medical Research Committee and of the Committee for Colonial Agricultural, Animal Health and Forestry Research, and the second annual reports of the Colonial Insecticides Committee and Colonial Economic Research Committee. That from the Colonial Research Council is the master report covering the whole field, including those of the specialist advisory bodies, and to it are appended a list of schemes approved for research grants under the Colonial Development and Welfare Acts during the period April 1, 1948-March 31, 1949, and of allocations for research under those Acts, 1940March 31, 1949. Some of the information has already been given in the return of schemes published in July as Colonial 211 and in "The Colonial Territories (1948-1949)" (Cmd. 7715), to which reference has already been made (see $\Lambda$ ature, August 6, p. 199). Actual disbursements on research schemes during the year under review amounted to about $£ 750,000$ as against $£ 425,760$ in $1947-48$, and $£ 169,388$ in 1946-47. In addition to major schemes already noted as made during the year, this report refers particularly to those for the acquisition and equipment of the Sir Alfred Jones Medical Research Laboratory in Sierra Leone, the preparation of a flora of East Africa, research into the effects of 'Antrycide' injections on cattle in East Africa and provision for the appointments of directors of the projected West African Agriculture and Forestry Research and Veterinary Research Organisations, and for postgraduate training in Great Britain of prospective workers on fisheries and stored products research. A new series of "Colonial Research Publications" was instituted by the Colonial. Office for reports by persons engaged on research in the Colonial sphere financed by Government sources, and three reports in this series appeared during the year.

* Colonial Research, 1948-1949. (Cmd. 7739.) Pp. 134. (London: H.M. Stationery Office, 3949.) 2s. 6d. net. 


\section{No. 4168 September 17, $1949 \quad$ N A T U R E}

Reviewing the fields of research in succession, the Colonial Research Council records further research by the African Studies Branch of the Colonial Office into the contemporary history and problems of African administration. Lord Hailey was engaged in completing a report on systems of African native administration, including the organisation of the native courts, and the Colonial Local Government Advisory Panel has already proved its worth. Copies of a bibliography of published works on African land tenure are expected to be available shortly. In the sphere of anti-locust research, regional control services have been, or are being, established to prevent the formation of new swarms and thus to protect the agricultural development of Africa, and the work of the Anti-Locust Research Centre has continued to develop in close co-operation with the regional services. Increasing assistance is being given by the Building Research Station to Colonial governments and others interested in Colonial building, and the interchange of information has been facilitated since Mr. C. A. Atkinson took up his duties as Colonial liaison officer at the Building Research Station on June 1, 1948. A survey of costs and standards of accommodation of typical buildings was recently made in each Colony, and the standards which have been adopted for low-cost building are being reviewed.

While there appear to be possibilities in developing marine fisheries in British Guiana, Trinidad, British Honduras, the Caymans and the Bahamas, no great increase in the production of the sea fisheries seems likely elsewhere. There appear to be possibilities in the development of fish production by fish farming in many of the islands. In East Africa the Research Station at Jinja on Lake Victoria has already obtained valuable results in studies of the Mormyrids, the elephant-snouted fish, which has a high food value. The fisheries survey of the Gulf of Aden ended in March 1949, and there appear to be good possibilities for a canning industry in the Gulf. The MauritiusSeychelles survey continues to show an abundance of fish on the Seychelles, the Aldabras, Cosmoledo, the Saya de Malha, Nazareth and Fortune Banks, the Gt. Brandon and Sudan Banks, Mauritius and Rodriguez, and several shark livers with a high vitamin A potency have been obtained. During the year, plans were made for the establishment of a National Institute of Oceanography as an Admiralty responsibility. Colonial governments are being asked to appoint officers to act as correspondents with the Road Research Laboratory, and in accordance with the recommendations of the Brazzaville Conference, an International Scientific Committee for Trypanosomiasis Research has been established with a permanent secretariat in London, while the French and Belgian Governments have set up a Standing Trypanosomiasis Bureau at Leopoldville. The London Tsetse Fly and Trypanosomiasis Committee, in collaboration with the Colonial Insecticides Committee, continued to review the whole field of anti-trypanosomiasis work in British Africa, and considerable progress was made with the establishment of the West African Institute. It is hoped that experiments which are now in progress will help to evaluate the prophylactic value of 'Antrycide' and extend its practical application.

The report of the Colonial Products Research Council refers particularly to the opening of the Colonial Microbiological Research Institute at Trinidad. This is intended to be a research centre for all the Colonies. The Hankey Culture Collection now comprises 153 cultures, and these have been detailed in a catalogue forwarded to the British Commonwealth Type Culture Collection. Clinical trials have shown that dextrose can replace blood plasma to about 50 per cent, and the director of research of the Council, Sir John Simonsen, has been able to arrange with the Ministry of Food for a sufficient allocation of sugar for a firm to proceed with the trial manufacture of dextrose on a semi-commercial scale. With Sir Norman Haworth's retirement from the chair of chemistry at the University of Birmingham, work on the chemistry of sucrose will continue in Birmingham ; but that on starch will in future be carried out by Prof. S. Peat at the University College of North Wales, Bangor. The observation that the so.called ' $Q$ ' enzyme converts amylose into amylopectin points to a possible industrial application of the studies of Haworth and Peat of the action of enzymes on these two constituents of starch. In view of the interesting pharmacological properties of the pyridazine derivatives obtained from lævulinic acid by Dr. L. F. Wiggins and his collaborators, a number of compounds are being submitted for clinical trials. The report emphasizes the need of further work before all the problems associated with the development of conophor oil by heat treatment of the seeds from Tetracarpidium conophorum can be solved, and the disturbed conditions in Malaya have hindered the collection of rubber seed for the large-scale trials of the production of a second substitute for linseed oil. Prof. T. P. Hilditch's work has also made it clear that the oils obtained from niger seeds, safflower seed and sunflower seed of suitable varieties from East Africa and Rhodesia are of high linoleic acid content and of equal, if not superior, value in the paint industry to soya bean oil. The work has also indicated the importance of environmental conditions, temperature and soil on the cultivation of oil seeds. Work on the germination factor of Striga hermonthica indicates that the factor is a carbohydrate. Investigations on the alkylnaphthalenes in collaboration with Trinidad Leaseholds, Ltd., have led to the preparation of an alkylnaphthalene sulphonic acid comparable with the best commercial products in detergent and wetting properties. An analytical survey is being made of Colonial timbers, and saponin obtained from the wood of Mora excelsa and related timbers from British Guiana and Trinidad is being investigated.

The Colonial Social Science Research Council has continued to give much attention to the problem of providing an organisation capable of planning and conducting research in the Colonies themselves, and is confident that the solution lies in the creation of regional institutes of social and economic research, although as an interim measure a good case could be presented for the creation by Colonial governments of small departments or research branches to investigate such specific administrative problems demanding urgent remedies as land tenure, native law, etc. The first of these regional Institutes to be established in a Colonial territory is that at Makerere in Uganda; but its director, Dr. W. E. H. Stanier, has recently tendered his resignation after submitting lengthy reports on the requirements of the Institute itself and the social science research needs of Uganda and Tanganyika. A similar Institute has now been established in the West Indies with Dr. H. Dudley Huggins as its first director, and with the governing body of the University College of the West Indies as its own governing body. A third Institute is proposed for Nigeria to serve West Africa, and it is expected 
that this Institute will be similarly integrated with the University College at Ibadan. Among the projects in progress are the Ethnographic Survey of Africa, the Survey of the Northern Eantu Linguistic Border, anthropological research on the Mende, Sierra Leone, the social survey of Jamaica and linguistic research in Fiji. New projects undertaken during the year include historical research on the Gold Coast, a study of administration by native authorities in Nyasaland, anthropological studies of the Turkana, Kenya, and in Sarawak and Singapore, and a study of psychological aptitude testing in Nigeria.

The report of the Colonial Medical Research Committee refers to the arrangements being made for the East African Medical Survey, and for the continua. tion of the Virus Institutes in Uganda and Nigeria on the termination of support from the Rockefeller Foundation. Preliminary arrangements for setting up the East African Bureau of Medical Research have been completed, and arrangements made to take over the research laboratory at Freetown, Sierra Leone, from the Liverpool School of Tropical Medicine. The programme of research in hot-climate physiology is being developed in Nigeria under the direction of Dr. W. S. S. Ladell, while preliminary arrangements have been made for the development of new schemes of research on Bancroftian filariasis and onchocerciasis in East Africa and on loiasis in the Cameroons. Research on malaria in North Borneo continued, while in Malaya trials of the prophylactic value of 'Paludrine', mepacrine and chloroquine undertaken in the plantations of an endemic area appeared to confirm the high suppressive value of 'Paludrine' in falciparum and vivax malaria. It is also intended to compare the results obtained in control of malaria by D.D.T. or 'Gammexane' spraying of houses and by the use of 'Paludrine' prophylaxis in selected areas. The Malaria Sub-Committee has also drafted recommendations for the prophylactic and therapeutic use of 'Paludrine' for suppression and treatment of malaria.

Work on nutrition has continued at the Field Research Station at Fajara in the Gambia, and senior members of the Human Nutrition Research Unit of the Medical Research Council are now engaged in the Gambia in clinical investigations principally concerned with the prevalent types of anæmia, with liver pathology and œedema, and work has continued to determine the extent to which these conditions depend on malnutrition and zymotic disease. As a preliminary to long-term investigations on filarial infections in East Africa, the Medical Research Council dispatched a research team to Tanganyika to undertake field studies on the effect of hetrazan. The Colonial Medical Research Committee also asked Dr. F. Hawking and Lieut.-Colonel W. Laurie to report on the facilities available for research in filariasis in East Africa, and Mwanza has been selected as the headquarters of a Colonial Office team of which Lieut.-Colonel Laurie will be in charge. The ScrubTyphus Research Unit in Malaya is investigating the biology and ecology of carrier mites and of their animal hosts. Besides the ecological problems, the vexed question of taxonomy is receiving much attention, and close contact has been maintained with the United States Scrub-Typhus Research Unit, particularly in the field prophylaxis trials of chloromycetin, in which considerable strides were made in the study of the chemoprophylactic potentialities of the drug. Besides its curative value for scrub-typhus, this new antibiotic is effective against gonorrhœal urethritis. Physiological research at Makerere College, Uganda, has covered anæmia, hæmoglobin estimations and levels, and the condition of malignant malnutrition known as kwashiorkor.

The annual report of the Committee for Colonial Agricultural, Animal Health and Forestry Research records the considerable attention given by the Committee to the regional organisation of research in East Africa, as well as in West Africa and the Malayan region. An African Rinderpest Conference was held at Nairobi in October 1948 to consider the control and eradication of rinderpest in Africa, and much attention has been given to the question whether there is any danger of introducing rinderpest into the United Kingdom by the importation of immunized animals or the carcases of immunized animals. An ad hoc sub-committee recommended concentration of efforts on the eradication of the disease from wide areas of country containing large cattle populations. An International African Soils Conference held at Goma in November recommended the establishment of a research organisation, an Inter-African Pedological Service, at Yangambi in the Belgian Congo, and also of an International Information Bureau on questions of soil conservation and utilization with headquarters in Paris, and these recommendations are being implemented. The mission sent to Zanzibar in March 1949 to advise on methods to be taken to check the spread of 'sudden death' disease of clove trees on Pemba Island has submitted its report. The Cocoa Research SubCommittee has put forward tentative suggestions for implementing the recommendations of the Commission of Inquiry into the swollen shoot disease of cocoa in West Africa, and has again closely studied the work of the West African Cacao Research Institute. The Stored Products Research SubCommittee has been chiefly concerned with the activities of the West African Pest Infestation Survey and particularly with the outbreak of Trogoderma infestation among stored groundnuts in the area of Kano, Northern Nigeria.

The Colonial Insecticides Committee reports that the Colonial Insecticides Research Team is now at work at Porton, near Salisbury, and has obtained interesting results on the influence of crystal size on toxicity to mosquitoes and tsetse flies and the application of this factor to the composition of wettable powders. The effects of particle size and distribution on toxicity are being studied. The Colonial Insecticides Research Unit, Uganda, has given much attention to aircraft experiments against tsetse flies, and experiments with impregnated sereens indicate that this method may be useful as a subsidiary method of control. Further trials with ground insecticidal smoke generators have confirmed that both D.D.T. and B.H.C. smokes are lethal to tsetse flies, but application still presents difficulties. Sprays of these insecticides have also been used in field experiments on the control of malaria by spraying native huts. The Unit's new headquarters will be in Tanganyika. The need for fundamental research in this field is stressed in the report, which also refers to the work on mosquito eradication in Cyprus, malaria control in Malaya, the malaria eradication experiment in Mauritius, the disinfestation of aircraft, helicopter experiments, the control of grasshoppers on sugar cane in Trinidad, the disinfestation of trains against tsetse and the preliminary trials with herbicides against weeds of groundnuts and with defoliants 


\section{No. 4168 September 17, $1949 \quad$ N A T URE}

on bush vegetation carried out at Kongwa for the Overseas Food Corporation.

The Colonial Economic Research Committee states in its brief second report that the Committee has been concerned with advising the Colonial Office on technical economic problems arising in the appreciation of economic conditions in Colonial territories, and has collaborated with the Colonial Office in preparing a comprehensive programme of Colonial economic research to be undertaken as and when qualified research workers become available. Two research studies undertaken by Colonial Research Fellows, and supervised by the Committee, are being prepared for publication, namely, Miss P. Deane's inquiry into national income, production and expenditure in Northern Rhodesia and Nyasaland, and Miss P. Ady's study of the occupational structure of representative communities in the Gold Coast as influenced by war-time Government expenditure.<smiles></smiles>

J. B. DELAMBRE (1749-1822)

By ENG.-CAPT. EDGAR C. SMITH, O.B.E.

EAN BAPTIFTE SOSEPH DELAMBRE, an $\int$ illustrious FInch astronomer, was born at Amiens on pept hber 19, 1749. He was educated at the gyennmium of his native town, and there came under thinfluence of the poet Delille, with whom ho b tin a life-long friendship. Afterwards, he was effold to attend the College of Plessis in Paris, and at the close of his academic career began to earn a precarious living by the aid of his pen. His knowledge of languages was extensive, and he made many translations from Greek, Latin, Italian and English. He also undertook the duties of a private tutor, continuing meanwhile his own studies in mathematics.

At about the age of thirty-five, Delambre attended lectures at the Collège de France and there formed a friendship with Lalande. His first important scientific work was the preparation of the tables of the newly discovered planet Uranus, for which he received in 1790 a prize from the Academy of Sciences. Two years later, he was awarded a second prize, for his tables of Jupiter and Saturn, and was also elected a member of the Academy.

In 1790 the Revolutionary Government in France brought forward the project of determining a national system of weights and measures, and in connexion with this a commission. including Lagrange, Laplace, Pruny and Delambre was formed to consider the matter. Besides the length of the seconds pendulum, two other units of length were suggested, namely, a quarter of the earth's circumference at the equator and a quadrant of the meridian. The latter was the one accepted, and Delambre and Mechain were detailed to measure an arc from Dunkirk to Barcelona. The operation extended over the years $1792-99$, and the results were given to the world by Delambre in his work entitled "Base du System metrique decimal", the first volume being .published in 1806, the third in 1810. Owing to the unsettled state of the country, the work of measurement was often difficult and dangerous, and at one time the operations were suspended altogether by a decree of Robespierre, who deposed Delambre and some of his colleagues from the commission as being deficient in "republican virtues and their hatred of kings". Arago and Biot eventually extended the arc measured by Delambre and Mechain to Foramentera.
Delambre was given a seat in the Bureau des Longitudes, in 1802 he was appointed inspectorgeneral of studies, and in the following year he was chosen permanent secretary to the Paris Academy of Sciences, in which capacity he wrote many éloges, reports, etc. In 1807 he succeeded Lalande at the Collège de France, and in 1808 was made treasurer of the Imperial Ministry. As an acknowledgment of his merits the Institute of France in 1810 gave him one of the decennial prizes instituted by Napoleon; but the Emperor for some reason refused to ratify the decision. The latter part of Delambre's life was taken up by his numerous duties and the collection of materials for his great "History of Astronomy". This work appeared in six volumes, five being pub. lished between 1817 and 1821 and the last in 1829, five years after his death. He died in Paris on August 19, 1822, after suffering for some time from severe fainting fits.

Delambre was distinguished no less for his impartiality than for his profound learning. "He was a man in whom the love of truth and accuracy was conspicuous. Learned and patient, he spared no pains in acquiring knowledge and in using it to the best purpose. He laboured as earnestly to restore to Hipparchus the credit due to him as to hold the balance between the merits of French and British astronomers. His character was as amiable as his life was blameless, and the frugal and simple habits of his early life were not abandoned when he occupied a distinguished position and was a chevalier of St. Michael and an officer of the Legion of Honour." His éloge was pronounced by Cuvier, who paid an eloquent tribute to his memory.

\section{OBITUARIES}

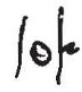

\section{Prof. S. H. Reynolds}

By the death of Sidney Hugh Reynolds on August 20, geology has lost op who made important con. tributions both as investigator and as a teacher. Born at Brightoed in 1867, he passed from Marl. borough to finity College, Cambridge, where he studied natural science and, under the influence of T. Mckentry Hughes and J. E. Marr, began to spegialite in geology.

Fin was appointed to the staff of University College, Btistol, in 1894, teaching both geology and zoology under Lloyd Morgan. This wide range of activities was not unattractive to him, for he was fundamentally a naturalist with an interest in all field studies. Indeed, his text-book on "The Vertebrate Skeleton" remained for many years a standard work for students of zoology, while much later he showed how this interest had been continued by undertaking the preparation of Volume 3 (1922-39) of the Palæontographical Society's monographs on the Pleistocene Mammalia, the first two volumes of which had been written by Boyd Dawkins in 1872 and 1878. But his principal work in Bristol was in field geology, and he was appointed to the chair of geology in 1910, a position which he held until his retirement in 1933.

Reynolds's geological writings cover a wide variety of topies. His early work dealt with the Lower Palæozoic rocks of western Ireland; in this he collaborated with C. I. Gardiner, with whom he continued to work for many years. As his interest in the Bristol district grew, he wrote many papers on local 